Original Article

\title{
AN INVESTIGATION OF THE ANALGESIC AND ANTI-INFLAMMATORY EFFECTS OF AERIAL PARTS OF FLACOURTIA JANGOMAS
}

\section{JOTHIMANIVANNAN, P. LALITHA, K. MEENA, A. MEENAJESILIYA, J. C. MOGANAPRIYA, P. MANIMEKALAI*}

\author{
Swamy Vivekanandha College of Pharmacy, Elayampalayam Namakkal 637205
}

Email: mekalaivel@gmail.com

Received: 30 Jan 2021, Revised and Accepted: 15 May 2021

\section{ABSTRACT}

Objective: The present study was aimed to evaluate the analgesic and anti-inflammatory effects of leaf and stem part aqueous extract of Flacourtia jangomas.

Methods: Aqueous extract of leaves (ALE) and aqueous extract stem (ASE) part of Flacourtia jangomas were sequentially prepared by maceration process and subjected to a preliminary phytochemical screening. The anti-inflammatory activity was assessed by the carrageenan-induced acute rat paw oedema model and Analgesic activity was evaluated by acetic acid-induced writhing model and hot plate method in mice. The data were analysed by one-way ANOVA followed by post hoc Dunnet's test by using SPSS V.15 (student trail version)

Results: The preliminary phytochemical analysis of extracts of leaves and stems indicated the presence of carbohydrate, alkaloids flavonoids, phenols, tannins, saponins. The extracts showed significant anti-inflammatory and analgesic activities with a dose-dependent manner. The ethanolic extract from the leave extract of Flacourtia jangomas at the dose $200 \mathrm{mg} / \mathrm{kg}$ has $55.6 \%$ significant anti-inflammatory activity compared to the standard drugs (44.4\%). Even at the low dose leave extract has more potent than aqueous stem extract. Where in analgesic effect by Hot plate method basal reaction time results showed that aqueous extract of stem part at the dose of $200 \mathrm{mg} / \mathrm{kg}$ has a significant effect at $120 \mathrm{mts} 10.0 \mathrm{sec}$ when compared with std pentazocine $13.0 \mathrm{sec}$. In peripheral analgesic method Acetic acid-induced writhing model results have not shown much more significant when compared with standard drug (42.1\%). The potential to cause anti-inflammation by stem extract was comparatively less than that of leave extract. Thus it could be concluded that Flacourtia jangomas leave extract possess significant anti-inflammatory activity

Conclusion: Our findings suggest that Flacourtia jangomas extract is safe and has potential anti-inflammatory and analgesic activities, which promote this use as a food supplement against pain and inflammation related to inflammatory diseases.

Keywords: Anti-inflammatory, Carrageenan, Analgesics, Acetic acid, Pentazocine

(C) 2021 The Authors. Published by Innovare Academic Sciences Pvt Ltd. This is an open access article under the CC BY license (https://creativecommons.org/licenses/by/4.0/)

DOI: https://dx.doi.org/10.22159/ijpps.2021v13i7.42597. Journal homepage: https://innovareacademics.in/journals/index.php/ijpps.

\section{INTRODUCTION}

Flacourtia jangomas is an important member of the family Flacourtiaceae showing a variety of medicinal uses and found in the lowland and mountain rain forest tree [1]. It is widely cultivated in southeast and East Asia and as escaped cultivation in number of places [2]. The family includes 87 genera and about 900 species and the genus Flacourtia includes 7 species. The species under study is very commonly found in lowland and mountain rain forest tree. It is widely cultivated in the southeast and East Asia and as escaped cultivation in a number of places [2] Aerial parts of the plant is used in the treatment of diabetics, asthma, anemia and antibacterial, antidiarrheal, antioxidant activities [3]. Fruits are widely eaten as pickles, jams, juice [4]. Dried roots are used to suppress toothache [5]. Phytochemical studies of $F$. jangomas revealed several bioactive constituents, including carbohydrates, protein, lipids, alkaloids, glycosides, tannins, etc [6]. Flacourtia Montana, a related species used as hepatoprotective, anti-inflammatory and antioxidant activities [7]

The plant has also been investigated pharmacologically for antidiabetics, antibacterial, antioxidant; analgesic, antifungal activities [8]. The related species of F. Montana, F. spare, F. ignoramus' and F. romance have been reported with various pharmacological activities like antibacterial, antidiabetic, anti-inflammatory and hepatoprotective [9]. The analgesic and anti-inflammatory activity of Flacourtia jangomas on the methanolic extract was already reported with methanolic extract. So we curious to know the same effect with high polar solvent to know the analgesic and anti-inflammatory activity in aqueous extract of Flacourtia jangomas

The current study aimed to validate the traditional use of $F$. jangomas in the management of inflammatory condition and pain. In the present study, we have chosen the plant Flacourtia jangomas used in herbal medicine to determine its anti-inflammatory activity and Analgesic activity.

\section{MATERIALS AND METHODS}

\section{Animals}

Swiss albino mice $(20-25 \mathrm{~g})$ and Wistar rats $(200-250 \mathrm{~g})$ of both sexes were obtained from the animal house facility Department of Pharmacology, Swamy Vivekanandha College of Pharmacy, Elayampalayam, Tiruchengode, Namakkal. The animals were housed in plastic cages under standard conditions with 12 hrs light: dark cycle with free access to food and water. The study was conducted after obtaining approval (Reg. No. 1158/PO/AC/18) by the Institutional Animal Ethics Committee and was performed in accordance with the Committee for the Purpose of Control and Supervision of Experiments on Animals (CPCSEA) guidelines.

\section{Chemicals}

The following chemicals were used in the experiments: Carrageenan diclofenac sodium, Carboxymethylcellulose (CMC), Pentazocine, Acetic acid were purchased from (India)

\section{Plant materials}

The whole plant of Flacourtia jangomas (Flacourtiaceae) was collected from Pallikkara, Thiruvalla, Pathanamthitta (Dt), Kerala, in November, 2017 and identified by Dr. S. Senthil Kumar (Botanist) at the department of botany, Vivekanandha College of Arts and Sciences for women, Namakkal.

Phytochemical procedure

\section{Extraction}

Leaves and stem of Flacourtia jangomas were washed thoroughly with water to remove the soil particles, shade dried and grounded. About $800 \mathrm{~g}$ of leaf powder was extracted with $2500 \mathrm{ml}$ of distilled 
water by cold maceration. About $150 \mathrm{~g}$ of stem powder was extracted with $500 \mathrm{ml}$ of distilled water by cold maceration. After completion of the extraction, it was filtered and dried to produce a semisolid mass. The dried extract was stored in a desiccator until use.

\section{Preliminary phytochemical analysis}

Flacourtia jangomas extract was subjected to preliminary phytochemical screening through qualitative chemical analysis for confirmation of the phytoconstituents $[10,11]$.

\section{Acute toxicity tests}

Swiss Albino rat weighing 200-250 g selected by random sampling were used in this study. Acute oral toxicity was performed as per OECD-423 guidelines. The animals were fasted overnight, provided only with water. The extracted was administered orally at the dose level of $5 \mathrm{mg} / \mathrm{kg}$ body weight by gastric intubations and the animals were observed for 14 days. The animals were observed for toxic symptoms such as pain, Fur movement, Lachrymal secretion, Nose fluid secretion, Allergy, Pupil size and Diameter, eye colour, body weight, convulsion, mortality for $72 \mathrm{~h}[12]$.

\section{Pharmacological activity}

Anti-inflammatory activity (Carrageenan induced paw oedema in rat)

Anti-inflammatory activity of the aqueous plant extract of Flacourtia jangomas was assessed by using a carrageenan induced acute paw oedema model. The albino Wistar rats of both sexes were divided into 6 groups of 4 animals each. Food was withdrawn overnight, but adequate supply of water was given to the rats before the experiment. Group 1 serving as control received 1\% w/v carboxy methylcellulose suspension orally. Group 2 serving as standard received $20 \mathrm{mg} / \mathrm{kg}$ Diclofenac. Group 3 and 4 received 200, 400 $\mathrm{mg} / \mathrm{kg}$ of Flacourtia jangomas leaf extract respectively. Group 5 and 6 received 200, $400 \mathrm{mg} / \mathrm{kg}$ of Flacourtia jangomas stem extract respectively. The drugs were given orally with the help of an oral catheter. After $1 \mathrm{hr}$ a sub-plantar injection of $0.1 \mathrm{ml}$ of $1 \%$ carrageenan was administered in the right hind paw to all the 6 groups. The paw volume was measured with the help of plethysmograph immediately after injection. The paw volume observed after 1, 2 and 3h [13]. Mean increase in the paw volume was measured and percent inhibition was calculated [14].

Percentages of inhibition were obtained using the following ratio:

Percentage inhibition $=\frac{(\mathrm{Vt}-\mathrm{Vo}) \text { control }-(\mathrm{Vt}-\mathrm{Vo}) \text { treated }}{(\mathrm{Vt}-\mathrm{Vo}) \text { control }} \times 100$
Vt is the average volume for each group after treatment, Vo is the average volume for each group before any treatment.

\section{Analgesic activity}

\section{Hot plate method}

Analgesic activity of the aqueous plant extract of Flacourtia jangomas was assessed by heat. The Hot plate method was performed by Eddy and Leimbach. The pre-screened swiss albino mice showed the reaction time of 3 to $5 \mathrm{Sec}$ and were selected and randomly divided into six groups of four mice per group. Group - 1 were given $1 \%$ CMC solution $10 \mathrm{ml} / \mathrm{kg}$ (control), Group - 2 were given pentazocine 4 $\mathrm{mg} / \mathrm{kg}$ i. p.(standard), while Group - 3 and Group - 4 received 200 and $400 \mathrm{mg} / \mathrm{kg}$ of leaf extract of Flacourtia jangomas, Group - 5 and Group - 6 received 200 and $400 \mathrm{mg} / \mathrm{kg}$ of stem extract of Flacourtia jangomas. Extract respectively all by gastric gavage. Animals were placed on Eddy's hot plate maintained at $55 \pm 1{ }^{\circ} \mathrm{C}$. The reaction time in control and treated animals was recorded till they showed licking or jumping movements [15]. The cut-off time was considered as $10 \mathrm{Sec}$. The reaction time was recorded at $0,30,60,90$, and 120 min following administration of the test drug.

\section{Acetic acid-induced writhing method}

Acetic acid-induced writhing model was performed by the method of koster et al., with slight modification. Twenty four albino mice of both sexes were randomly divided into six groups of four mice per group. Group - 1 were given $1 \%$ CMC solution $10 \mathrm{ml} / \mathrm{kg}$ (control), Group - 2 were given diclofenac sodium $20 \mathrm{mg} / \mathrm{kg}$ i. p. (Standard), while Group - 3 and Group - 4 were received 200 and $400 \mathrm{mg} / \mathrm{kg}$ of leaf extract of Flacourtia jangomas, Group - 5 and Group -6 received 200 and $400 \mathrm{mg} / \mathrm{kg}$ of stem extracts of Flacourtia jangomas. Extracts respectively all by gastric gavage. One hour after administration of drug and extract, $0.6 \%$ glacial acetic acid $(10 \mathrm{ml} / \mathrm{kg})$ was given i. p. to all the mice to induce pain characterized by abdominal constrictions are wriths. The number of wriths observed in each mouse was counted for $10 \mathrm{mins}$ and recorded [16-18]. The percentage protection against abdominal writhing was used to assess the degree of analgesia and was calculated using the formula,

$$
\% \text { inhibition of writhing }=\frac{\text { No. of wriths in control }- \text { No. of wriths intreated group }}{\text { No. of wriths in control group }} \times 100
$$

\section{Statistical analysis}

The results of the study were expressed as Mean \pm SEM and statistical significance between control and treated groups, standard and treated groups evaluated by one-way ANOVA followed by post hoc Dunnet's multiple comparison test by using SPSS V.15 (Student trail version). $\mathrm{P}<0.05$ was considered significant.

Table 1: Showing the preliminary phytochemical screening of leaf and stem part of Flacourtia jangomas

\begin{tabular}{|c|c|c|c|}
\hline S. No. & Test & Aqueous extract of leaf & Aqueous extract of stem \\
\hline \multirow[t]{4}{*}{1} & CARBOHYDRATES & & \\
\hline & a) Molisch test & + & + \\
\hline & b) Fehling's test & + & + \\
\hline & c) Benedict test & + & + \\
\hline \multirow[t]{4}{*}{2} & ALKALOIDS & & \\
\hline & a) Dragondroff's test & + & + \\
\hline & b) Mayer's test & + & + \\
\hline & c) Hager's test & - & - \\
\hline 3 & SAPONINS: & + & + \\
\hline \multirow[t]{4}{*}{4} & GLYCOSIDES & & \\
\hline & a. Legal's test & - & - \\
\hline & b. Balget's test & - & - \\
\hline & c. Bontrager's test & + & + \\
\hline 5 & FLAVONOIDS & + & + \\
\hline 6 & PROTEINS and AMINO ACIDS & + & + \\
\hline \multirow{2}{*}{7} & STEROIDS & & \\
\hline & a) Salkowski test & + & + \\
\hline 8 & TANNINS and PHENOLIC COMPOUNDS: & + & + \\
\hline
\end{tabular}

+Presence-Absence 


\section{RESULTS}

\section{Preliminary phytochemical analysis}

The aqueous extract of Flacourtia jangomas was subjected to a preliminary phytochemical screening revealed the presence of carbohydrates, alkaloids, saponins, glycosides, flavonoids, proteins, tannins and steroids.

\section{Acute toxicity test}

The aqueous extract of Flacourtia jangomas produced no toxic symptoms or mortality up to a dose level of $2000 \mathrm{mg} / \mathrm{kg}$ body weight orally in rats, Hence the drug was considered safe for further pharmacological screening. So $1 / 10^{\text {th }}$ and $1 / 5^{\text {th }}(200 \mathrm{mg}$ and $400 \mathrm{mg}$, respectively) of toxic dose were selected for all in vivo experiments submaximal and maximal dose.

\section{Anti-inflammatory activity}

The anti-inflammatory effect of aqueous extract of Flacourtia jangomas was assayed in the carrageenan-induced paw edema in rat. The injection carrageenan when injected into a sub-plantar region of the rat paw produced localized edema that reached to its maximum at the $3^{\text {rd }} \mathrm{h}$ after injection. The localized inflammatory response to carrageenan was sustained for $4 \mathrm{~h}$ and gradually declined after this time.

As shown in table 2, Flacourtia jangomas produced a marked reduction in carrageenan-induced paw edema $(55.6 \%$ at $200 \mathrm{mg} / \mathrm{kg}$ leaf extract) at the $3^{\text {rd }} \mathrm{h}$. The difference between the paw volume of the control and extracts treated animals was statistically significant $(\mathrm{p}<0.001)$ at the $2^{\text {nd }} \mathrm{h}$ of the observation. The standard drug Diclofenac sodium at $20 \mathrm{mg} / \mathrm{kg}$ produced about $44.4 \%$ inhibition of the carrageenan-induced edema as shown in table 1.

Table 2: Anti-inflammatory effect of leaf and stem part of Flacourtia jangomas on carrageenan-induced acute paw oedema in Wistar albino rats

\begin{tabular}{|c|c|c|c|c|c|c|}
\hline \multirow[t]{2}{*}{ Treatment } & \multicolumn{5}{|c|}{ Increase in paw volume in ml (Mean \pm SEM) } & \multirow{2}{*}{$\begin{array}{l}\% \text { inhibition } \\
\text { after } 3 \mathrm{~h}\end{array}$} \\
\hline & Oh & $1 / 2 \mathrm{~h}$ & 1h & $2 \mathbf{h}$ & 3h & \\
\hline $1 \% \mathrm{CMC}$ & $0.25 \pm 0.03$ & $0.55 \pm 0.03$ & $0.65 \pm 0.03$ & $0.55 \pm 0.03$ & $0.45 \pm 0.03$ & - \\
\hline $\begin{array}{l}\text { Diclofenac sodium } 20 \mathrm{mg} / \mathrm{kg} / p . o+0.1 \mathrm{ml} \\
\text { Carrageenan }\end{array}$ & $0.25 \pm 0.03$ & $\begin{array}{l}0.35 \pm 0.03 \\
a^{* * *}\end{array}$ & $\begin{array}{l}0.30 \pm 0.01 \\
a^{* *}\end{array}$ & $\begin{array}{l}0.30 \pm 0.01 \\
a^{* * *}\end{array}$ & $\begin{array}{l}0.25 \pm 0.03 \\
a^{* * *}\end{array}$ & $44.4 \%$ \\
\hline ALE-200 mg $/ \mathrm{kg} / p . o+0.1 \mathrm{ml}$ Carrageenan & $0.20 \pm 0.01$ & $\begin{array}{l}0.33 \pm 0.03 \\
a^{* * *}\end{array}$ & $\begin{array}{l}0.23 \pm 0.03 \\
a^{* *}, b^{*}\end{array}$ & $\begin{array}{l}0.23 \pm 0.03 \\
\mathrm{a}^{* * *}, \mathrm{~b}^{*}\end{array}$ & $\begin{array}{l}0.20 \pm 0.01 \\
\mathrm{a}^{* * *}\end{array}$ & $55.6 \%$ \\
\hline ALE-400 mg $/ \mathrm{kg} / p . o+0.1 \mathrm{ml}$ Carrageenan & $0.20 \pm 0.01$ & $\begin{array}{l}0.35 \pm 0.03 \\
a^{* * *}\end{array}$ & $\begin{array}{l}0.23 \pm 0.03 \\
a^{* * *}, b^{*}\end{array}$ & $\begin{array}{l}0.23 \pm 0.03 \\
a^{* * *}, b^{*}\end{array}$ & $\begin{array}{l}0.23 \pm 0.03 \\
a^{* * *}\end{array}$ & $48.9 \%$ \\
\hline ASE-200 mg $/ \mathrm{kg} / p . o+0.1 \mathrm{ml}$ Carrageenan & $0.23 \pm 0.05$ & $\begin{array}{l}0.33 \pm 0.03 \\
a^{* * *}\end{array}$ & $\begin{array}{l}0.25 \pm 0.03 \\
a^{* * *}\end{array}$ & $\begin{array}{l}0.23 \pm 0.03 \\
\mathrm{a}^{* * *}, \mathrm{~b}^{*}\end{array}$ & $\begin{array}{l}0.25 \pm 0.03 \\
a^{* * *}\end{array}$ & $44.4 \%$ \\
\hline ASE- $400 \mathrm{mg} / \mathrm{kg} /$ p. o+0.1 ml Carrageenan & $0.25 \pm 0.06$ & $\begin{array}{l}0.40 \pm 0.01 \\
\mathrm{a}^{* * *}\end{array}$ & $\begin{array}{l}0.30 \pm 0.01 \\
a^{* * *}\end{array}$ & $\begin{array}{l}0.30 \pm 0.01 \\
a^{* * *}\end{array}$ & $\begin{array}{l}0.25 \pm 0.03 \\
\mathrm{a}^{* * *}\end{array}$ & $44.4 \%$ \\
\hline
\end{tabular}

Values are expressed as Mean \pm SEM, $n=4$, the symbol represents statistical significance: $a=$ comparison of Group-1 Vs Group-2,3,4,5 and 6; $b=$ comparison of Group-2 Vs Group-1, 3,4,5 and 6. ${ }^{* * *} \mathrm{P}<0.001,{ }^{* *} \mathrm{P}<0.01$ and ${ }^{*} \mathrm{P}<0.05$, one way ANOVA by Dunnet's multiple comparison test as compared to control and standard.

Table 3: Central analgesic activity of aqueous extract of Flacourtia jangomas on reaction time to hot plate method in mice

\begin{tabular}{lllll}
\hline Treatment & \multicolumn{2}{l}{ Basal reaction time (sec) } & \\
\cline { 2 - 5 } & Basal & $\mathbf{3 0 ~} \mathbf{~ m i n}$ & $\mathbf{6 0} \mathbf{~ m i n}$ & $\mathbf{9 0} \mathbf{~ m i n}$ \\
\hline 1\% CMC & $7.3 \pm 0.67$ & $6.7 \pm 0.88$ & $8.3 \pm 0.33$ & $9.3 \pm 0.76$ \\
Pentazocine (4 mg/kg i. $p$ & $7.3 \pm 0.20$ & $9.3 \pm 0.88^{*}$ & $15.0 \pm 0.45^{* *}$ & $13.0 \pm 0.15$ \\
ALE-200 mg/kg/p. o & $7.6 \pm 0.88$ & $8.0 \pm 0.15$ & $11.0 \pm 0.08$ & $9.0 \pm 0.58$ \\
ALE-400 mg/kg/p. o & $8.0 \pm 0.52$ & $8.7 \pm 0.32$ & $9.3 \pm 0.85$ & $9.3 \pm 0.88$ \\
ASE-200 mg/kg/p. o & $9.0 \pm 0.57$ & $8.3 \pm 0.23$ & $12.7 \pm 0.10^{*}$ & $10.3 \pm 0.88$ \\
ASE-400 mg/kg/p. o & $8.0 \pm 0.58$ & $9.3 \pm 0.67^{*}$ & $11.0 \pm 0.73$ & $10.0 \pm 0.52$ \\
\hline
\end{tabular}

Values are expressed as Mean \pm SEM, $n=4$, the symbol represents statistical significance: $a=$ comparison of Group-1 Vs Group-2,3,4,5 and 6; $b=$ comparison of Group-2 Vs Group-1, 3,4,5 and $6 .{ }^{* * *} \mathrm{P}<0.001,{ }^{* *} \mathrm{P}<0.01$ and ${ }^{*} \mathrm{P}<0.05$, one way ANOVA by Dunnet's multiple comparison test as compared to control and standard.

Table 4: Peripheral analgesic activity of Flacourtia jangomas on acetic acid induced writhing method in mice

\begin{tabular}{lll}
\hline Treatment & Total no. of writhing (in 10 min) & \% Inhibition \\
\hline $1 \%$ CMC & $44.33 \pm 1.76$ & - \\
Pentazocine $(4 \mathrm{mg} / \mathrm{kg}$ i. p $+0.6 \%$ Acetic acid) & $25.67 \pm 4.84^{* *}$ & $42.1 \%$ \\
ALE-200 mg/kg/p. o+0.6\% Acetic acid & $28.00 \pm 7.57^{*}$ & $36.8 \%$ \\
ALE-400 mg/kg/p. o+0.6\% Acetic acid & $52.00 \pm 1.58$ & - \\
ASE-200 mg/kg/p. $0+0.6 \%$ Acetic acid & $29.33 \pm 4.18^{*}$ & $33.8 \%$ \\
ASE-400 mg/kg/p. $0+0.6 \%$ Acetic acid & $52.67 \pm 2.33$ & - \\
\hline
\end{tabular}

Values are expressed as Mean \pm SEM, $n=4$, the symbol represents statistical significance: $a=$ comparison of Group-1 Vs Group-2,3,4,5 and 6; $b=$ comparison of Group-2 Vs Group-1, 3,4,5 and $6 .{ }^{* *} \mathrm{P}<0.001,{ }^{* *} \mathrm{P}<0.01$ and ${ }^{*} \mathrm{P}<0.05$, one way ANOVA by Dunnet's multiple comparison test as compared to control and standard.

\section{DISCUSSION}

Anti-inflammatory activity of Flacourtia jangomas was determined by the carrageenan-induced acute paw edema model, which is one of the most feasible methods of screen anti-inflammatory agents. The carrageenan-induced acute inflammation is biphasic, in the early phase (1-2 h after carrageenan injection), edema production is mediated by histamine, serotonin and kinins while in the late phase 
(after $2 \mathrm{~h}$ ), the inflammatory response is maintained by bradykinin and prostaglandins [19]. These mediators are well established for their role in an inflammatory reaction which is measured at $3 \mathrm{~h}$. In the present investigation, Flacourtia jangomas exhibit marked antiinflammatory activity in the early phase of carrageenan-induced edema test similar to diclofenac, a standard non-steroidal antiinflammatory drug (NSAID). Aqueous extract of Flacourtia jangomas produced a significant $(\mathrm{p}<0.001)$ inhibition of carrageenan-induced paw edema at $2 \mathrm{~h}$ in a dose-dependent manner. Therefore, it can conclude that the inhibitory effect of aqueous extract of Flacourtia jangomas on carrageenan-induced inflammation could be due to inhibition of the inflammatory enzyme cyclooxygenase and subsequent inhibition of prostaglandin synthesis, significant inhibition of paw edema in the yearly hours after carrageenan injection by Flacourtia jangomas could be attributed to the inhibition of prostaglandin [20].

Antinociceptive activities of aqueous extract of Flacourtia jangomas were evaluated by acetic acid-induced writhing method and hot plate method. This method allows the analysis of peripheral and centrally mediated antinociceptive responses respectively.

The hot plate method is commonly used to assess the centrally acting analgesics. The analgesic activity of Flacourtia jangomas was tested upon adult mice by the hot plate method. The aqueous extract of stem at lower dose of $200 \mathrm{mg} / \mathrm{kg}$ shows significant ( $\$ 0.05$ ) analgesic activity when compared to standard pentazocine $4 \mathrm{mg} / \mathrm{kg}$.

The aqueous stem extract $(200 \mathrm{mg} / \mathrm{kg}$ ) may be activate the opioid receptor at the interneuronal level, which produces hyperpolarisation of the neurons, result in the inhibition of the firing and the release of tachykinin neuropeptides, a neurotransmitter involved in pain transmission, thereby blocking the pain transmission that causes a prolongation of the hot plate latency by this model must be acting centrally [21].

The analgesic activity of Flacourtia jangomas was tested upon adult mice by acetic acid-induced writhing method. The aqueous extract of leaf and stem at low dose of $200 \mathrm{mg} / \mathrm{kg}$ shows significant $(\mathrm{p}<0.05)$ analgesic activity when compared to standard diclofenac sodium $20 \mathrm{mg} / \mathrm{kg}$. Bradykinin, neurokinins and prostanoids are known mediators for acetic acid-induced writhing $[22,24]$. The effect of the aqueous leaf and stem extracts of Flacourtia jangomas at low concentration produces antinociceptive activity. It may be depressed the production of irritants and their by reduction in the number of writhes on the mice.

The abdominal contraction induced by acetic acid is a sensitive produced to establish peripherally acting antinociceptives. This response is thought to involve local peritoneal receptor [23]. The result of the current study indicates the analgesic effect of Flacourtia jangomas, might be mediated by inhibiting the synthesis or acting on peripherally acting nociceptive.

The present study reveals that the leaf and stem part of aqueous extract of Flacourtia jangomas found to possess the peripheral and central analgesic activity and significant anti-inflammatory activity.

\section{CONCLUSION}

In conclusion, our results reveals that among all the extracts of leaves and stem of Flacourtia jangomas aqueous extracts exhibited significant analgesic and anti-inflammatory activities. These findings validated the claim for the traditional use of this plant in the treatment of pain and inflammatory ailments activities. In addition to this, research regarding the mechanism responsible for these activities is also required which will guarantee its clinical worth.

\section{ACKNOWLEDGEMENT}

The study substantiates the traditional use of $F$. jangomas as a remedy of inflammatory and pain condition. The finding of this study will help natural product researcher to identify the active constituent of this plant and precise underlying mechanism as possible anti- inflammatory and analgesic drug candidate with good safety and tolerability profile.

\section{AUTHORS CONTRIBUTIONS}

All authors have contributed equally in this piece of work

\section{CONFLICT OF INTERESTS}

The authors declared no conflict of interest

\section{REFERENCES}

1. Talukdar C, S Saha, S Adhikari, HK Mondal, MdK Islam, Md Anisuzzman, et al. Evaluation of antioxidant, analgesic and antidiarrhoeal activity of Flacourtia jangomas (Lour.) raeusch leaves. Pharmacol Online 2012;3:20-8.

2. Hanlet, Peter. Institute of plant genotics and crop plant research. eds. Mansfeld's. Encyclopedia of Agricultural and Horticultural crops [Except ornamentals] springer; 2001. p. 3700.

3. Neelakandan T. International journal of current medical and pharmaceutical research. Print and online Publication; 2016. p. 69.

4. Anonymous. Flacourtia comm. (Flacourtiaceae). In: The Wealth of India: Raw Materials, CSIR, New Delhi; 1956;4:42-4.

5. Ashalata Devi Khumbongmayum AO, ML Khan, RS Tripathi. Ethnomedicinal plants in the sacred groves of Manipur. IJTK 2005;4:21-32.

6. Ghani A. Medicinal plants of Bangladesh: chemical constituents and uses. Dhaka. Asiatic Soc Bangladesh 2003;5:1-16.

7. Ajay Kumar Singh, Jyoti Singh. Evaluation of the anti-diabetic potential of leaves and stem of flacourtia jangomas in streptozotocin-induced diabetics in rat. Indian J Pharmacol 2010;42:301-5.

8. Chinchu Joshy PA, R Thahimon, Arun Kumar, Betty Carla, Christudas Sunil. Hepatoprotective, anti-inflammatory and antioxidant activities of flacourtia monata J. Grah leaf extract in male wistar rats. Bull Faculty Pharm Cario University 2016;54:209-17.

9. Wu Jian, Danielsson Ake, A Zern Mark. Toxicity of hepetotoxins: new insights into mechanisms and therapy. Expert OpinInvestig Drugs 1999;8:585-607.

10. Ferrero Miliani L, OH Nielsen, PS Andersen, SE Girardin. Chronic inflammation: importance of NOD2 and NALP3 in interleukin-1 beta generation. Clin Exp Immunol 2007;147:227-35.

11. Sajeesha Sasi, Nishat Anjum, YC Tripathi. Ethnomedicinal, phytochemical andpharmacological aspects of flacourtia Jangomas: a review. Int J Pharm Pharm Sci 2018;10:9-5.

12. Venkatesa Perumal R, M Adiraj, P Shanmuga Pandiyan. Synthesis, analgesic and anti-inflammatory evaluation of substituted 4-piperidones. Indian Drugs 2001;38:156-9.

13. Ramprasath VR, P Shanthi, P Sachdanadanam. Antiinflammatory effect of Semecarpus anacardium Linn. Nut extract in acute and chronic inflamm cond. Biol Pharm Bull 2004;27:2028-31.

14. Eddy NB, D Leimbach. Synthesis analgesics. 2. Dithienyl butenyl and dithienbutylamines. J Pharmacol Exp Ther 1953;107:385-93.

15. Koster R, M Anderson, EJ De Beer. Acetic acid for analgesics screening; 1959;18:412-8.

16. Uddin SJ, JA Shilpi, J Barua, R Rouf. Antinociceptive activity of ceripes decandra leaf and pneumetophore. Fitoterapi 2005;76:261-3.

17. Muhshina Ferdous, Razina Rouf, Jamil Ahmad Shilpi, Shaikh Jamal Uddin. Antinociceptive activity of the ethanolic extract of ficus racemosa lin. (Moraceae) 2008;8:93-6.

18. Tambewagh UU, AD Kandhare, VS Honmore, PP Kadam, VM Khedkar. Anti-inflammatory and antioxidant potential of guaianolide isolated from cyathocline purpurea: role of COX-2 inhibition. Int Immunopharmacol 2017;52:110-8.

19. Toma W, JS Graciosa, CA Hiruma Lima, FDP Andrade, W Vilegas, ARMS Brita, et al. Evaluation of the analgesic and antiedematogenic activities of quassia amara bark extract. J Ethnopharmacol 2003;85:19-23.

20. Ibironke GF, KI Ajiboye. Studies on the anti-inflammatory and analgesic properties of chenopodiun ambrosioides leaf extract in rats. Int J Pharm 2007;3:111-5. 
21. Ikeda $\mathrm{Y}, \mathrm{A}$ Ueno, $\mathrm{H}$ Naraba, $\mathrm{S}$ Ohrishi. Involvement of vanilloid receptor VRI and prostanoids in the acid induced writhing responses of mice. Life Sci 2001;69:2911-9.

22. Chakraborty AR, RK Devi, S Rita, KH Sharatchandra, TI Singh. Preliminary studies on anti-inflammatory and analgesics activities of spilanthes acmella in experimental animal models. Indian J Pharmacol 2004;36:148-50.

23. Laaboudi W, J Ghanam, H Aissam, M Merzouki, M Benlemlih Anti-inflammatory and analgesic activities of olive tree extract. Int J Pharm Pharm Sci 2016;8:414-9. 